\title{
Teaching NeuroImages: Intradural, intramedullary spinal cord metastasis from primary renal cell carcinoma
}

Muhammad Taimur Malik, MD, Syed Jaffar Kazmi, MD, and Scott Turner, MD Neurology ${ }^{\circledR}$ 2018;90:e911-e912. doi:10.1212/WNL.0000000000005072

Correspondence

Dr. Malik

mamalik@geisinger.edu

Figure $1 \mathrm{MRI}$ and CT imaging
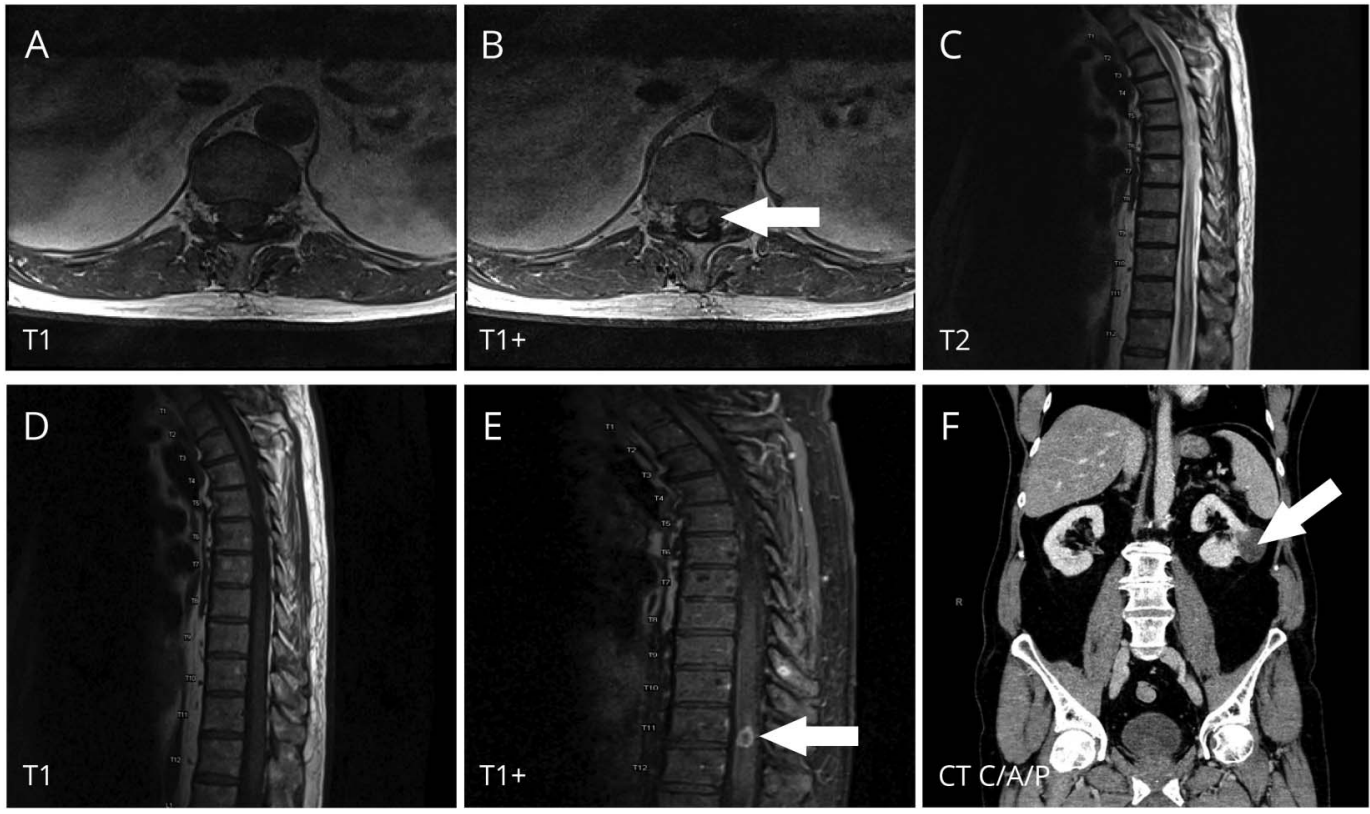

(A) Axial view of MRI of the thoracic spine without contrast. (B) Axial view of MRI of the thoracic spine with contrast shows contrast enhancement of the intramedullary intradural lesion as depicted by the arrow. (C) Sagittal view of the MRI thoracic spine shows T2 sequence. (D) Sagittal view of MRI of the thoracic spine without contrast. (E) Sagittal view of MRI of the thoracic spine with contrast shows contrast enhancement of the intradural intramedullary lesion (arrow). (F) CT chest, abdomen, and pelvis shows the left renal mass (arrow).

A 75-year-old man with hypertension presented with 2 weeks' history of left lower extremity numbness and weakness. Initial neurologic examination revealed $4 / 5$ muscle strength in the left lower extremity with intact reflexes and decreased left-sided sensation. MRI of the thoracic spine revealed a mass with surrounding edema at T11-12 (figure 1, A and B). CT chest, abdomen, and pelvis showed left renal mass (figure 1F). Biopsy showed stained cells, positive for PAX8 and vimentin and negative for glial fibrillary acidic protein, which was consistent with renal cell carcinoma (figure 2). The patient underwent surgical excision and radiotherapy. Intradural intramedullary metastatic lesions are a rare manifestation of primary renal cell cancer. $^{1,2}$

\section{MORE ONLINE}

$\rightarrow$ Download teaching slides

links.lww.com/WNL/A299 


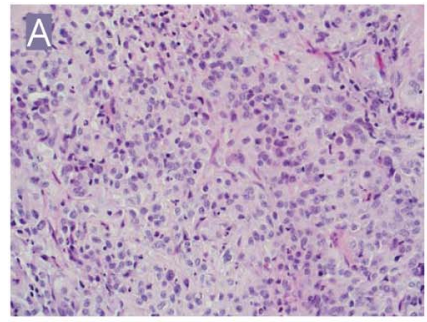

$\mathrm{H} \& \mathrm{E}$

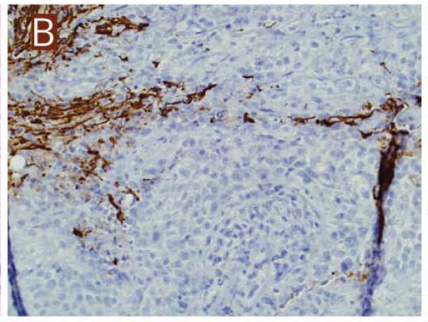

GFAP

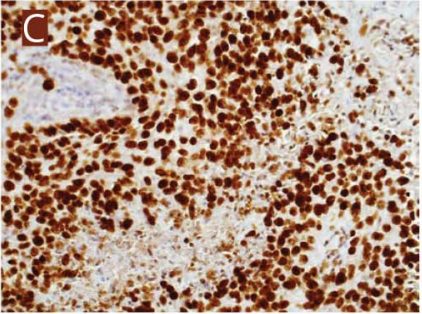

PAX 8

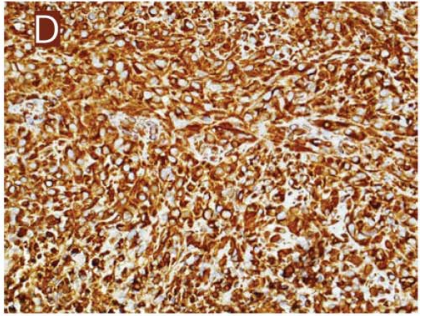

Vimentin

(A) Hematoxylin \& eosin (H\&E)-stained section shows metastatic carcinoma composed of epithelial cells with moderate clear cytoplasm and round to slightly irregular hyperchromatic nuclei. Some of the nuclei contain small nucleoli. There are thin fibrovascular septa traversing the tumor staining of the biopsy specimen. (B) Glial fibrillary acidic protein (GFAP) immunostain is negative in tumor cells. (C, D) Tumor is positive for PAX8 (C), vimentin (D), and CD10 (not shown), consistent with renal cell carcinoma (A-D magnification $\times 200)$.

\section{Author contributions}

M.T. Malik assisted in the clinical assessment of the patient, edited the images, and wrote the manuscript. S. Kazmi assisted with the histopathologic images and edited the images and the manuscript. S. Turner performed the patient's clinical assessment and performed critical revision of the manuscript.

\section{Study funding}

No targeted funding reported.

\section{Disclosure}

The authors report no disclosures relevant to the manuscript. Go to Neurology.org/ $\mathrm{N}$ for full disclosures.

\section{References}

1. Grem JL, Burgess J, Trump DL. Clinical features and natural history of intramedullary spinal cord metastasis. Cancer 1985;56:2305-2314.

2. Connolly ES Jr, Winfree CJ, McCormick PC, Cruz M, Stein BM. Intramedullary spinal cord metastasis: report of three cases and review of the literature. Surg Neurol 1996;46:329-337. 


\section{Neurology}

\section{Teaching NeuroImages: Intradural, intramedullary spinal cord metastasis from primary renal cell carcinoma}

Muhammad Taimur Malik, Syed Jaffar Kazmi and Scott Turner

Neurology 2018;90;e911-e912

DOI 10.1212/WNL.0000000000005072

\section{This information is current as of March 5, 2018}

\section{Updated Information \&} Services

\section{References}

Subspecialty Collections

\section{Permissions \& Licensing}

\section{Reprints}

including high resolution figures, can be found at: http://n.neurology.org/content/90/10/e911.full

This article cites 2 articles, 0 of which you can access for free at: http://n.neurology.org/content/90/10/e911.full\#ref-list-1

This article, along with others on similar topics, appears in the following collection(s):

MRI

http://n.neurology.org/cgi/collection/mri

Other Education

http://n.neurology.org/cgi/collection/other_education

Spinal cord tumor

http://n.neurology.org/cgi/collection/spinal_cord_tumor

Information about reproducing this article in parts (figures,tables) or in its entirety can be found online at:

http://www.neurology.org/about/about_the_journal\#permissions

Information about ordering reprints can be found online:

http://n.neurology.org/subscribers/advertise

Neurology ${ }^{\circledR}$ is the official journal of the American Academy of Neurology. Published continuously since 1951, it is now a weekly with 48 issues per year. Copyright (O) 2018 American Academy of Neurology. All rights reserved. Print ISSN: 0028-3878. Online ISSN: 1526-632X.

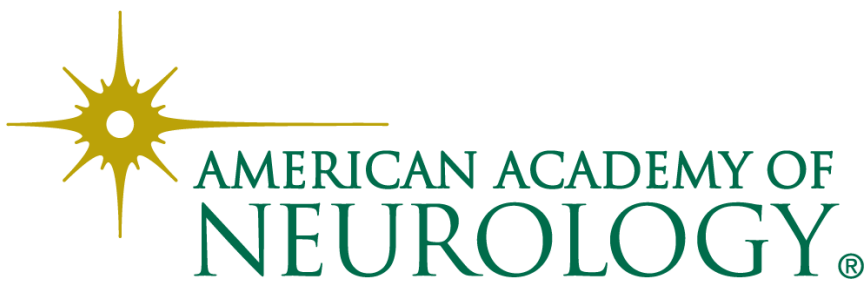

